\title{
Aspek Biologi Reproduksi Sebagai Dasar Pengelolaan Sumberdaya Rajungan (Portunus pelagicus, Linn 1758) di Perairan Toronipa, Konawe
}

\section{Aspects of Reproductive Biology as A Basic of Management of Blue Swimming Crab (Portunus pelagicus, LINN 1758) in Toronipa Waters of Konawe}

\author{
Muhammad Irfan Basri ${ }^{\left.1{ }^{*}\right)}$, La Sara ${ }^{2)}$, Yusnaini ${ }^{2)}$ \\ ${ }^{1)}$ Program Studi Ilmu Perikanan Program Pascasarjana Universitas Halu Oleo, Kendari, Indonesia \\ ${ }^{2)}$ Fakultas Perikanan dan Ilmu Kelautan Universitas Haluo Oeo, Kendari, Indonesia \\ Corresponding author ${ }^{*}$ : muhammad.irfan.basri@gmail.com; lasara_unhalu@yahoo.com; yusyusnaini@ymail.com
}

\begin{abstract}
The aim of this study was to know aspects of biological reproductive (sex ratio, phases and index of gonad development, fecundity, and size of the first gonad mature) of blue swimming crab (BSC $=P$. pelagicus) in Toronipa waters. This study was conducted from May to October 2014. Samples were collected monthly using simple random. Each sample obtained was identified its sex dan measured its carapace width (CW) using caliper $(0.05 \mathrm{~mm})$ and weighed its body weigh using electronic balance $(1 \mathrm{~g})$. Total of samples collected were 179 males and 191 females. The berried female BSC obtained was released its eggs fron its pleopd to to count its number of eggs.

Sex ratio of male and female obtained was counted and analyzed using Chi-square-test $(\alpha=0,05)$. Gonad maturity level (GML) BSC obtained was observed with its carapace was opened. Development of its GML was categorized into 5 class differentiated according to form, size, and color following the procedure of Costa and NegreirosFransozo (1998) and Sumpton et al (1994). Gonad somatic index (GSI) was computed using formula of GSI = (gonad weight/total body weight)* $100 \%$. Its fecundity was counted using a "raising factor" method, while the relationship between fecundity and body weight was analyzed using an simple linear regression equation.

The results of study showed sex ratio of male and female was $0.96: 1$, although this sex ratio is equal ( $<<0.05)$. The BSC had high percentage of GML III and IV which tended to dominant every month. The GSI ranged $3.45-$ $5.06 \%$. The peak GSI was found in May $(5.06 \%)$, while the lowest was in July (3.45\%). The reproduction potential (fecundity) of BSC ranged $0.48 * 10^{6}-2.98 * 10^{6}$. The size of first gonad maturity of BSC male $(72.4 \mathrm{~mm})$ was smaller than that of female $(78.5 \mathrm{~mm})$. All those data obtained indicate that BSC in this waters need to be serious managed as it was showed by data of very small size at first size maturity $(<10 \mathrm{~cm})$ which implies that BSCs have been heavy exploited. The BSC having GML III and IV will not give reproduction potential if there is intensive exploitation. The fecundity of BSCs have strong correlation with CW size - the largest of CW is the bigest of fecundity.
\end{abstract}

Keywords: Portunus pelagicus, Reproductive biology, Sex ratio, Fecundity, Size at first maturity, Gonad maturity index

\begin{abstract}
ABSTRAK
Tujuan penelitian ini adalah untuk mengetahui aspek biologi reproduksi (rasio kelamin, tahap dan indeks perkembangan gonad, fekunditas dan ukuran pertama matang gonad) rajungan ( $P$. pelagicus) di perairan Toronipa. Penelitian ini dilaksanakan pada Mei - Oktober 2014. Sample rajungan diperoleh setiap bulan secara acak. Setiap sample yang diperoleh didentifikasi jenis kelaminnya dan diukur lebar karapas menggunakan caliper ketelitian $0,05 \mathrm{~mm}$, dan ditimbang bobot tubuhnya menggunakan timbangan digital ketelitian $1 \mathrm{~g}$. Total sampel yang diperoleh 179 individu jantan dan 191 individu betina. Rajungan betina yang mempunyai telur (berried
\end{abstract}


female) dilepaskan dari pleopodnya untuk dianalisis fekunditasnya.

Sex ratio antara rajungan jantan dan betina yang diperoleh dihitung dan dianalisis menggunakan uji Chi-square $(\alpha$ $=0,05$ ). Tingkat kematangan gonad (TKG) sample yang diperoleh diamati dengan cara membuka karapasnya. Perkembangan kematangan tersebut dikategorikan kedalam lima kelas yang dibedakan berdasarkan bentuk, ukuran dan warna gonad mengikuti prosedur Costa dan Negreiros-Fransozo (1998) dan Sumpton et al. (1994). Indeks Kematangan Gonad (IKG) juga dihitung menggunakan rumus: IKG = (berat gonad/berat tubuh total)*100\%. Fekunditas rajungan dihitung menggunakan metode "raising factor", sedang hubungan f ekunditas dan b obot tubuh rajungan dianalisis menggunakan persamaan regresi linear sederhana.

Hasil penelitian menunjukan rasio $\mathrm{J}: \mathrm{B}$ adalah 0,96 : 1, walaupun demikian rasio tersebut termasuk seimbang $(\mathrm{p}<$ 0.05). Rajungan diperairan ini mempunyai persentase tinggi pada TKG III dan IV yang cenderung dominan setiap bulan yang mempunyai IKG berkisar 3,45 - 5,06\%. Puncak IKG terjadi pada bulan Mei $(5,06 \%)$, sedang terendah pada bulan Juli $(3,45 \%)$. Kemampuan reproduksi (fekunditas) organisma ini berkisar $0,48^{*} 10^{6}$ $2,98 * 10^{6}$. Ukuran pertama matang gonad rajungan jantan lebih kecil $(72,4 \mathrm{~mm})$ dibadingkan dengan rajungan betina $(78,5 \mathrm{~mm})$. Pengelolaan rajungan di perairan ini harus hati-hati karena ukuran pertama matang gonad sangat kecil $(<10 \mathrm{~cm})$, yang menunjukan bahwa rajungan di perairan ini mempunyai tingkat eksploitasi tinggi. TKG III dan IV tidak akan memberi potensi reproduksi jika eksploitasi dilakukan intensif. Fekunditas rajungan di perairan ini berhubungan dengan ukuran lebar karapas, yaitu semakin besar lebar karapas maka semakin besar jumlah fekunditas.

Keywords: Portunus pelagicus, Biologi reproduksi, Nisbah kelamin, Fekunditas, Ukuran pertama gonad, Indeks kematangan gonad

\section{DOI: http://dx.doi.org/10.33772/jspi.v1n2.}

\section{PENDAHULUAN}

Penyebaran rajungan (Portunus pelagicus) hampir ditemukan di perairan tropis kecuali Tasmania (Stephenson dan Campbell 1959), dimulai dari Indo Pasifik, Japan, Phillipines, Thailand, Malaysia sampai ke Indonesia dan Australia. Organisme ini umumnya tersebar di perairan tropis (Kailola et al. 1993) dan muara dekat pantai (Ayal dan Ozogul, 2011) dengan substrat pasir, pasir berlumpur dan habitat lamun hingga kedalaman $50 \mathrm{~m}$ (Williams, 1982; Edgar, 1990; La Sara et al. 2016a; 2016b; 2017).

Organisme ini mempunyai permintaan konsumen yang tinggi sehingga mempunyai nilai ekonomi penting pada pasar internasional (Kamrani et al. 2010). Kondisi ini berdampak pada tingkat eksploitasinya yang tinggi. Diantara negara penghasil rajungan dunia, Indonesia memberi kontribusi $\pm 20 \%$ dari produksi ekspor dan menjadi peringkat ke-2 setelah China pada tahun 2008 (NMFS, 2012).

Sulawesi Tenggara merupakan salah satu daerah penghasil rajungan yang berperan besar dalam kontribusi tersebut. Konsekuensinya adalah populasi rajungan menunjukan punurunan nyata dan beberapa nursery ground telah mengalami degradasi akibat penebangan bakau yang luas. Data hasil tangkapan yang terdapat di beberapa mini plant rajungan membuktikan hal ini. Data hasil tangkapan rajungan yang dikumpulkan sebuah miniplant di Konawe selama 3 tahun terakhir ini terus menurun yaitu 35,73 ton tahun 2011, 30,22 ton tahun 2012 dan 24,59 ton tahun 2013. Data yang sama juga ditunjukan oleh data miniplant di Bombana juga mengalami hasil tangkapan yang menurun selama 2 tahun terakhir, yaitu 12,3 ton tahun 2011 dan 9,41 ton tahun 2012 . Hasil observasi dan wawancara dengan nelayan di Toronipa, Torokeku, Kasipute dan Teluk Lasongko diperoleh data bahwa hasil tangkapan rajungan saat ini telah mengalami penurunan. Penuruan populasi rajungan tersebut diindikasikan oleh ukuran lebar karapas $(\mathrm{CW})$ rajungan yang tertangkap semakin kecil $(\mathrm{CW}<6 \mathrm{~cm})$, CPUE $2-3 \mathrm{~kg} /$ trip, rajungan tidak ditemukan lagi pada fishing gound (La Sara et al. 2016a; 2016b).

Perairan Toronipa merupakan salah satu lokasi aktivitas penangkapan rajungan oleh nelayan setempat dan juga dari daerah lain, seperti nelayan dari Tapulaga, Mekar, Bajo Indah, Soropia, Waworaha dan lain-lain. Penurunan populasi rajungan tersebut telah memprihatinkan semua pihak, terutama nelayan yang selama ini menggantungkan hidupnya pada sumber daya ini. Permasalahan semakin kompleks karena data hasil tangkapan tidak tercatat dengan baik. Data aspek reproduksi biologi sebagai salah satu dasar pengelolaan organisme ini juga tidak diketahui. Hasil 
tangkapan yang dikumpulkan nelayan selama penelitian dapat diprediksi fluktuasi perubahan populasi dan aspek reproduksi biologinya.

Studi tentang biologi reproduksi rajungan di perairan (rasio kelamin, tahap perkembangan gonad, ukuran pertama kali matang gonad, indeks kematangan gonad, dan fekunditas) penting dilakukan. Hasil penelitian ini dapat mendukung perumusan pengelolaan populasi rajungan di perairan ini.

\section{METODE PENELITIAN}

Penelitian ini dilaksanakan bulan Mei - Oktober 2014 di perairan Toronipa. Perairan ini merupakan salah satu lokasi penangkapan rajungan di perairan Sulawesi Tenggara. Stasiun pengambilan sample merupakan fishing ground rajungan di perairan ini yang dibagi dalam dua stasiun berdasarkan kedalaman perairan yang berbeda. Fluktuasi suhu dan salinitas di perairan ini cenderung stabil sepanjang tahun.

\section{Pengumpulan Data}

Sampel rajungan dikumpulkan secara acak menggunakan alat tangkap bubu rajungan (collapsible trap). Sample rajungan diperoleh dari hasil tangkapan sendiri dan dari nelayan. Setiap sample yang diperoleh diidentifikasi jenis kelaminnya berdasarkan morfologi abdomennya, diukur CW) menggunakan kaliper ketelitian $0,05 \mathrm{~mm}$, dan ditimbang bobot tubuhnya menggunakan timbangan digital ketelitian 1 g. Semua sample tersebut diidentifikasi jenis kelaminnya. Sample yang diperoleh terdiri atas 179 individu jantan dan 191 individu betina.

Rajungan betina yang mempunyai telur (berried female) dilepaskan dari pleopodnya kemudian ditimbang menggunakan timbangan digital ketelitian $0,01 \mathrm{~g}$, selanjutnya diawetkan dalam larutan alkohol $70 \%$ untuk dianalisis dan dihitung jumlah telur yang dimiliki (fekunditas) di laboratorium menggunakan mikroskop binokuler.

\section{Analisis Data}

Rasio jenis kelamin rajungan ditentukan dengan menghitung dan membandingkan jumlah individu jantan dan betina. Ekspektasi rasio jantan dan betina tersebut dianalisis dengan $C h i$-square-test pada $(\alpha=$ $0,05)$.

Tahapan perkembangan gonad untuk menentukan TKG rajungan diamati dengan membuka karapasnya. TKG tersebut dikategorikan kedalam lima kelas yang dibedakan berdasarkan bentuk, ukuran dan warna gonad mengikuti prosedur yang diadaptasi dari Costa and Negreiros-Fransozo (1998); Sumpton, et al., (1994), yaitu:

TKG I: bentuk gonad betina memanjang tipis, agak lunak berwarna putih susu atau kuning pucat, sedangkan gonad jantan terdiri dari sepasang filamen putih yang jernih atau putih susu.

TKG II: ukuran ovarium bertambah, warna kuning keemasan, butir telur belum kelihatan, sedang gonad jantan ukurannya bertambah besar dan berwarna putih susu atau kuning muda.

TKG III: volume ovarium hampir mengisi seluruh dada (chepalotorax), berwarna semakin kuning, butir telur mulai terlihat namun masih dilapisi oleh kelenjar minyak, sementara pada jantan gonadnya memanjang, hampir memenuhi ruang bagian punggung, berwarna putih pucat terkadang berwarna coklat muda.

TKG IV: butiran telur berwarna jingga (orange) dan mudah dipisahkan, lapisan minyak sudah berkurang, sementara jantan, gonadnya menyelubungi saluran pencernaan dan berwarna putih susu kekuningan.

TKG V: ovarium mulai mengecil, butiran telur sangat banyak terlihat pada bagian abdomen. Di sekitar hepatopankreas masih tampak butir telur yang tidak dikeluarkan, sedang pada jantan, gonadnya berwarna kuning kecoklatan, coklat tua atau coklat kehitaman dan menciut ke bagian koksopodit.

Indeks Kematangan Gonad (IKG) dihitung mengikuti formula dari Quinn and Kojis (1987):

\section{IKG $=($ berat gonad/berat tubuh total $) * 100 \%$}

Produktivitas telur (fekunditas) rajungan diestimasi menggunakan metode "raising factor" mengikuti formula dari La Sara (2001):

$$
F=n \frac{W}{w}
$$

dimana: $\mathbf{F}=$ fekunditas, $\mathbf{n}=$ rata-rata jumlah telur dari tiga sub sampel $(10 \%), \mathbf{W}=$ berat total telur, dan $\mathbf{w}=$ berat rata-rata dari tiga sub sampel telur (10\%).

Selanjutnya, hubungan jumlah telur dan bobot rajungan diplot pada kurva regresi linier menggunakan persamaan: 


$$
F=a B^{b}
$$

dimana: $\mathbf{F}=$ fekunfitas, $\mathbf{B}=$ bobot tubuh, dan $\mathbf{a}$ dan $\mathbf{b}=$ konstanta

Ukuran pertama matang gonad rajungan secara alamiah dianalisis menggunakan kurva determinasi antara persentase kumulatif (Y) dan lebar karapas (X). Ukuran tersebut (X) diperoleh pada persentase kumulatif $50 \%$ dari pengukuran lebar karapaks $\left(\mathrm{CW}_{50}\right)$ (Poovachiranon, 1992; La Sara, 2001).

\section{HASIL DAN PEMBAHASAN}

Hasil

\section{Nisbah Kelamin}

Sebaran rajungan berdasarkan nisbah jantan dan betina secara temporal pada bulan Mei - Oktober di perairan Toronipa (Gambar 1).

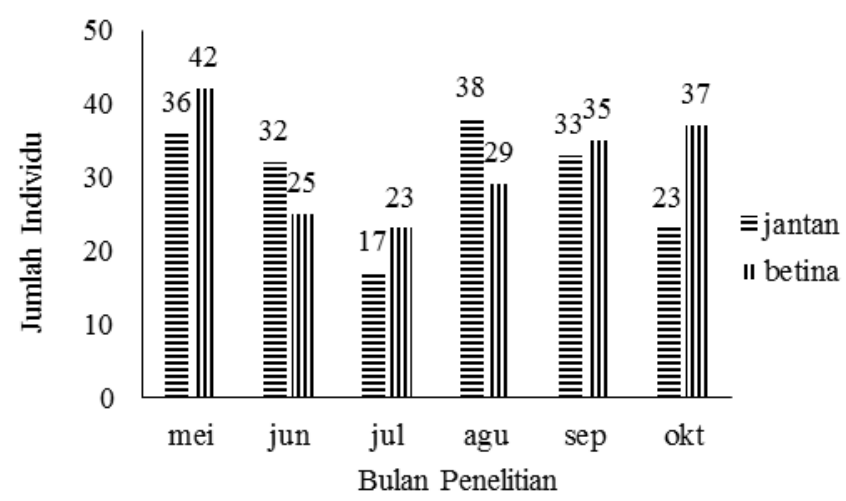

Gambar 1. Seabaran Nisbah Rajungan Jantan dan Betina di Perairan Toronipa

Nisbah kelamin rajungan adalah perbandingan jumlah jantan dan betina dalam suatu populasi yang biasa ditulis $\mathrm{M}$ : F (male : female). Jumlah rajungan jantan yang diperoleh 179 individu (48.1\%), sedangkan rajungan betina berjumlah 191 individu (51.9\%). Dengan demikian maka nisbah rajungan jantan betina adalah $0,96: 1$.

\section{Tingkat Kematangan Gonad (TKG)}

Sampel rajungan jantan dan betina yang diperoleh selama penelitian (370 individu) mempunyai TKG I TKG V, walaupun pada bulan tertentu tidak ditemukan rajungan menampakan TKG, seperti pada bulan Juni s/d Oktober tidak terdapat TKG V pada rajungan jantan, sedangkan pada Mei ditemukan TKG I - TKG V. Berbeda dengan penyebaran rajungan betina, TKG I tidak ditemukan pada bulan Juni,
Agustus, dan Oktober. Sample rajungan jantan paling banyak ditemukan TKG IV $(44,1 \%)$, dan sample rajungan betina terbanyak ditemukan TKG III (34\%) (Gambar 2).

\section{Gonado Somatic Index (GSI)}

Sejalan dengan pertambahan berat gonad pada rajungan jantan dan betina, maka akan diikuti dengan bobot tubuh sampai mencapai batas tertentu. Perubahan pertambahan gonad dan bobot tubuh tersebut memengaruhi nilai GSI rajungan jantan dan betina pada setiap bulan (Gambar 3).

Sebaran GSI secara temporal dapat digunakan untuk melihat periode pemijahan rajungan seiring dengan perkembangan TKG. Semakin tinggi TKG rajungan pada waktu tertentu, maka akan mempengaruhi persentase GSI rajungan pada waktu tersebut (Gambar 4).
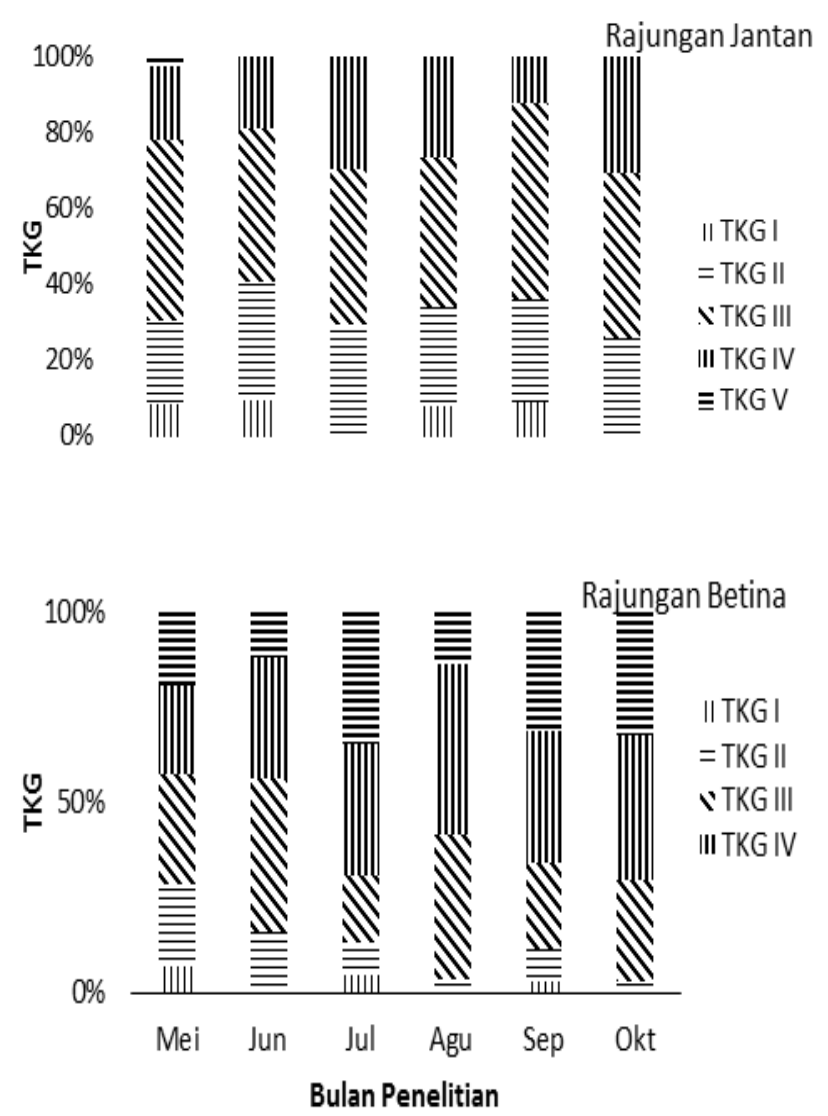

Gambar 2. Persentase Komposisi TKG Rajungan Jantan (atas) dan Betina (bawah) di Perairan Toronipa 


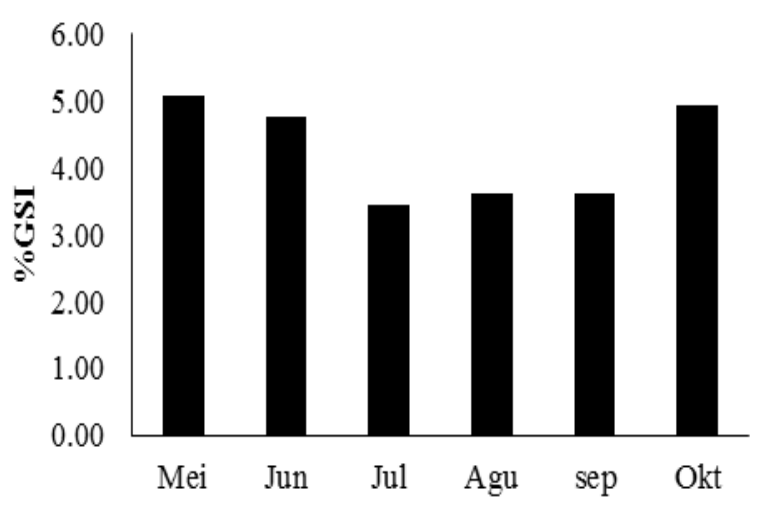

Gambar 3. Persentase Rata-Rata GSI rajungan di Perairan Toronipa

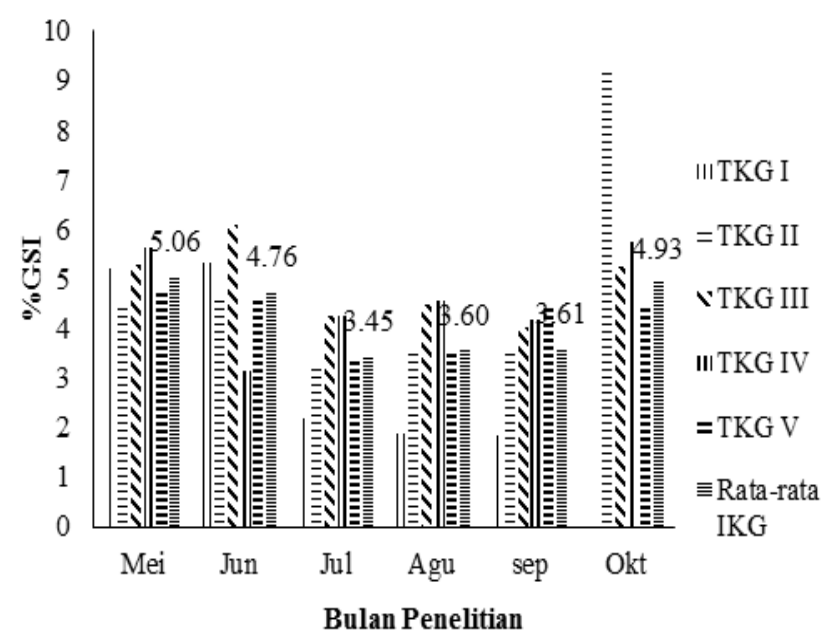

Gambar 4. Persentase sebaran GSI Secara Temporal pada Menurut TKG rajungan di Perairan Toronipa

\section{Fekunditas}

Rajungan betina (berried female) mempunyai fekunditas $0,48 * 10^{6}-2,98 * 10^{6}$. Jumlah fekunditas paling sedikit terdapat pada rajungan lebar karapas (CW) $87,15 \mathrm{~mm}$, sedang paling banyak terdapat pada rajungan $\mathrm{CW}$ 147,1 mm. Rajungan - seperti juga Portinidae lainnya - mempunyai pertumbuhan tidak linear karena organisme ini disebut "tumbuh" setelah mengalami molting, yaitu karapas lama terlepas kemudian digantikan dengan karapas baru. Molting terjadi apabila terjadi pertambahan bobot tubuh sehingga karapas lama tidak mampu lagi "menampungnya". Umumnya terdapat hubungan antara bobot tubuh dengan fekunditas (Gambar 5).

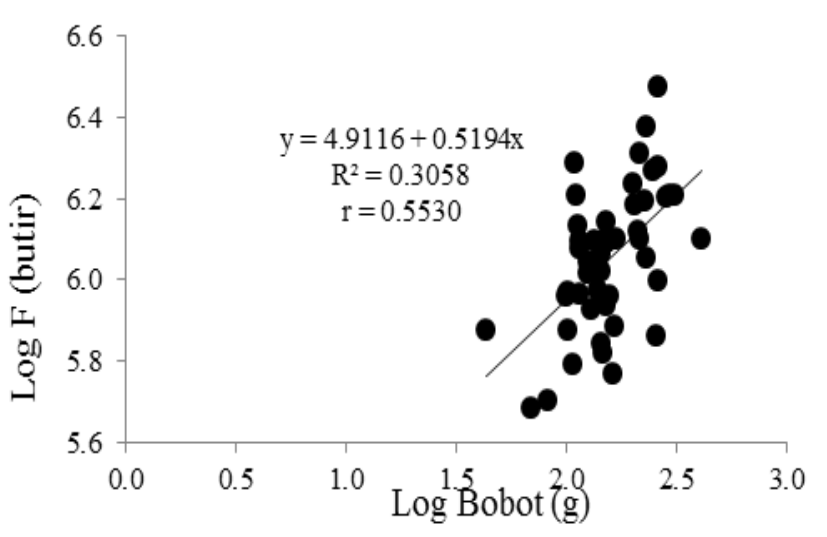

Gambar 5. Hubungan Fekunditas dan Bobot Tubuh Rajungan di Perairan Toronipa

\section{Ukuran Pertama Matang Gonad}

Sampel rajungan untuk analisis ukuran pertama matang gonad berjumlah 151 individu yang terdiri atas rajungan jantan 40 individu dengan kisaran $\mathrm{CW}$ 46,8 - 154,5 $\mathrm{mm}$ dan betina 111 individu dengan kisaran CW 55,4 - 168,2 mm. Ukuran pertama matang gonad rajungan $\left(\mathrm{CW}_{50}\right)$ ditentukan pada saat $50 \%$ kumulatif rajungan setiap ukuran $\mathrm{CW}(\mathrm{Y})$ kemudian di plot pada ukuran $\mathrm{CW}(\mathrm{X})$. Ukuran $\mathrm{CW}_{50}$ rajungan jantan dan betina masing-masing $72.4 \mathrm{~mm}$ dan 78,5 mm (Gambar 6).
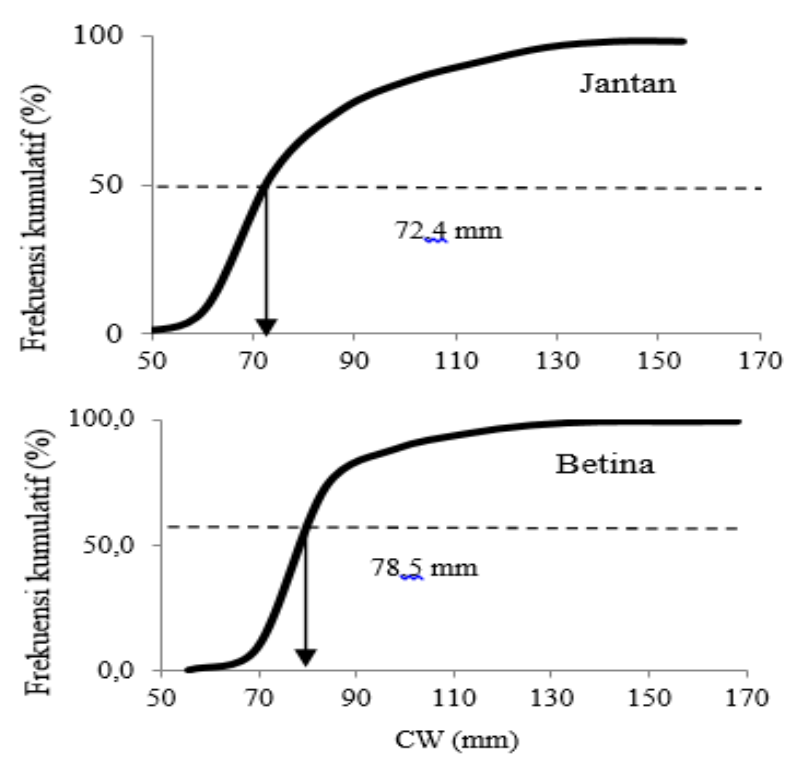

Gambar 6. Estimasi Ukuran CW Pertama Matang Gonad Rajungan Jantan (atas) dan Betina (bawah) di Perairan Toronipa 


\section{Pembasahan}

\section{Nisah kelamin}

Walaupun terdapat fluktuasi nisbah rajungan jantan dan betina setiap bulan (Gambar 2), secara keseluruhan rajungan betina lebih dominan dari rajungan jantan dengan nisbah 0,96:1, walaupun uji Chi-square nisbah kelamin tersebut menunjukan berbeda tidak nyata sehingga tergolong seimbang 1 : 1.

Fluktuasi nisbah kelamin setiap bulan dapat disebabkan oleh beberapa faktor, antara lain kompetisi antar jenis kelamin (Takween dan Qureshi, 2005), diferensiasi siklus hidup, pola recruitment, dan tingkat mortalitas pada setiap waktu. La Sara (2001) menjelaskan bahwa fluktuasi tersebut dapat disebabkan oleh jenis alat tangkap yang digunakan, lokasi dan waktu pengambilan sample.

\section{Tingkat Kematangan Gonad (TKG)}

Rajungan jantan dan betina yang mencapai TKG III dan TKG IV ditemukan setiap bulan (Mei Oktober) (Gambar 3) dengan persentase tertinggi pada Agustus. Data ini menjelaskan bahwa rajungan di perairan ini pada bulan-bulan tersebut telah mencapai ukuran dewasa, dan jumlah terbanyak terdapat pada bulan Agustus. Kamrani et al., (2010) menyatakan bahwa TKG III dan IV merupakan kelompok rajungan dewasa yang siap dan aktif dalam berkembang biak. TKG rajungan yang diperoleh dalam penelitian ini dapat menjelaskan perkembang biakkan rajungan di perairan ini terjadi minimal sepanjang waktu bulan Mei - Oktober seperti ditunjukan TKG III dan IV rajungan yang cukup tinggi.

Jika diasumsikan bahwa perkembangan TKG terjadi setiap bulan maka data penelitian ini juga menunjukkan TKG berkembang sampai ke tahap pemijahan terbanyak pada rajungan betina bertelur pada bulan September dan Oktober. Berdasarkan data tersebut menindikasikan bahwa puncak pemijahan rajungan di perairan ini terjadi pada bulan September - Oktober yang merupakan awal musim panas di perairan ini. Kunsook, et al, (2014) melaporkan TKG rajungan betina paling tinggi di Teluk Kung Krabaen, Thailand terdapat pada bulan Februari sampai Maret, September dan Desember, sedang terendah terdapat pada bulan Juni, Juli dan Agustus. Komposisi TKG matang rajungan betina paling banyak ditemukan pada bulan Februari dan Agustus, sedang yang terendah terdapat pada bulan Juni, Oktober,
November dan Desember. Svane dan Hooper (2004) melaporkan bahwa perkembangan ovarium tertinggi rajungan betina diamati pada akhir Oktober November bersamaan dengan meningkatnya suhu air laut. Data ini mengindikasikan bahwa diduga puncak rajungan mijah terjadi pada bulan-bulan tersebut.

Data pada Gambar 4 menunjukkan TKG I - IV terjadi hampir sepanjang bulan Mei - Oktober, kecuali pada bulan Oktober. Persentase rajungan TKG I tertinggi terdapat pada bulan Mei, sedang yang terendah terdapat pada bulan Oktober. Data ini menunjukan rajungan di perairan sepanajng bulan Mei - Oktober dominan ditemukan rajungan ukuran dewasa. Bagi rajungan betina berarti sudah masuk dalam tahap siap memijah (Kamrani, et al. 2010). Rajungan betina yang ditemukan setiap bulan sudah masuk kategori TKG V maka potensi reproduksi rajungan di perairan cukup baik sebagaimana ditunjukan oleh jumlah fekunditas yang cukup tinggi.

\section{Gonado Somatic Index (GSI)}

Grafik perubahan persentase nilai GSI rajungan jantan dan betina selama penelitian menunjukkan perubahan yang tidak bervariasi (Gambar 5). Nilai GSI setiap bulan untuk setiap TKG berkisar 3,45 $5,06 \%$. Nilai GSI tertinggi terjadi pada bulan Mei $(5,06 \%)$, diikuti bulan September dan Oktober, sedang terendah terjadi pada bulan Juli $(3,45 \%)$. Periode nilai GSI tertinggi tersebut dapat diduga akan merupakan musim pemijahannya.

Perbedaan nilai GSI tersebut diduga disebabkan oleh perbedaan awal kematangan seksual serta faktor lingkungan perairan. Soundarapandian et al.((2013) menjelaskan bahwa variasi nilai GSI portunidae pada setiap wilayah perairan sangat erat hubungannya dengan ukuran dan bobot tubuhnya.

Persentase nilai GSI rajungan jantan dan betina TKG III dan V cenderung seimbang selama waktu penelitian. Data ini selaras dengan hasil penelitian Kamrani, et al. (2010) yang menunjukkan hadirnya rajungan TKG III dan IV sepanjang waktu penelitiannya selam 1 tahun.

Dalam penelitian ini nilai GSI rajungan tertinggi terjadi pada bulan Mei $(5,06 \%)$, kemudian menurun pada bulan Juni $(4,76 \%)$ sampai pada bulan Juli $(3,45 \%)$. Nilai GSI tersebut mulai meningkat kembali pada bulan Agustus $(3,60 \%)$ hingga bulan September $(3,61 \%)$, walaupun laju pertambahannya relative kecil. Memasuki bulan Oktober peningkatan GSI sangat tinggi yaitu mencapai $4,93 \%$. Fluktuasi niai 
GSI setiap bulan berkaitan erat dengan perkembangan TKG rajungan. Semakin banyak rajungan yang matang gonad, maka nilai GSI diharapkan akan tinggi pula. Hal ini menunjukkan bahwa nilai GSI.

\section{Fekunditas}

Jumlah fekunditas rajungan di perairan ini berkisar $0,48 * 10^{6}-2,98 * 10^{6}$. Jumlah fekunditas ini berhubungan dengan ukuran CW. Semakin besar CW rajungan maka semakin besar pula jumlah fekunditas. Ukuran CW terbesar 147,1 mm mempunyai fekunditas tertinggi, sebaliknya CW terkecil 87,15 mm mempunyai fekunditas terendah. Dengan demikian maka variasi jumlah fekunditas berhubungan erat dengan perubahan ukuran CW (Clarke dan Ryan, 2004; Svane dan Hooper, 2004).

Data fekunditas yang diperoleh ini lebih besar dibandingkan dengan fekunditas rajungan yang tertangkap di perairan Bandar Abbas, Iran yang berkisar $0,27 * 10^{6}-1,11^{*} 10^{6}$, namun lebih sedikit bila dibandingkan dengan portunidae lain (Scylla serrata) yang ditemukan di perairan Teluk Lawelle, Indonesia yang mencapai $1,51 * 10^{6}-8,89 * 10^{6}$ (La Sara, et al., 2002) (Tabel 2).

Tabel 2. Fekunditas spesies kepiting berbeda di beberapa lokasi

\begin{tabular}{|c|c|c|c|}
\hline Lokasi & Spesies & Fekunditas & Referensi \\
\hline $\begin{array}{l}\text { Australia } \\
\text { Selatan }\end{array}$ & P.pelagicus & $\begin{array}{l}0,65 \times 10^{6}- \\
1.76 \times 10^{6}\end{array}$ & $\begin{array}{l}\text { Kumar,et } \\
\text { al. }(2000)\end{array}$ \\
\hline Teluk Lawele, & \multirow{3}{*}{$\begin{array}{l}\text { Scylla } \\
\text { serrata } \\
\text { P. pelagicus }\end{array}$} & $1,51 \times 10^{6}$ & \multirow{3}{*}{$\begin{array}{l}\text { La Sara,et } \\
\text { al., (2002) } \\
\text { de Lestang, } \\
\text { et al., (2003) }\end{array}$} \\
\hline Indonesia & & $8,89 \times 10^{6}$ & \\
\hline $\begin{array}{l}\text { Perairan Pesisir } \\
\text { Barat Australia }\end{array}$ & & $\begin{array}{l}0,78 \times 10^{6}- \\
1 \times 10^{6}\end{array}$ & \\
\hline $\begin{array}{l}\text { Perairan Pesisir } \\
\text { Bandar Abbas, } \\
\text { Iran }\end{array}$ & P. pelagicus & $\begin{array}{l}0,27 \times 10^{6}- \\
1,11 \times 10^{6}\end{array}$ & $\begin{array}{l}\text { Kamrani, } \\
\text { et al., } \\
(2010)\end{array}$ \\
\hline Perairan Estuary & \multirow{2}{*}{$\begin{array}{l}\text { Callinectes } \\
\text { sapidus }\end{array}$} & $0,15 \times 10^{6}-$ & \multirow{2}{*}{$\begin{array}{l}\text { Rodrigues, } \\
\text { et al. } \\
\text { (2011) }\end{array}$} \\
\hline Patos, Brazil & & $2,57 \times 10^{6}$ & \\
\hline Perairan Pesisir & \multirow[t]{2}{*}{ P. pelagicus } & $0,04 \times 10^{6}-$ & \multirow{2}{*}{$\begin{array}{l}\text { Ikhwanudd } \\
\text { in, et al. } \\
\text { (2012) }\end{array}$} \\
\hline Johor, Malaysia & & $1,83 \times 10^{6}$ & \\
\hline Perairan Pesisir & $P$. & $0,96 \times 10^{6}$ & Soundarap \\
\hline India & $\begin{array}{l}\text { sanguinolen } \\
\text { tus }\end{array}$ & $2,25 \times 10^{6}$ & $\begin{array}{l}\text { andian, et } \\
\text { al. }(2013)\end{array}$ \\
\hline Perairan Desa & P. pelagicus & $0,48 \times 10^{6}-$ & Penelitian \\
\hline $\begin{array}{l}\text { Toronipa, } \\
\text { Indonesia }\end{array}$ & & $2,98 \times 10^{6}$ & ini \\
\hline
\end{tabular}

La Sara et al. (2002) menyatakan bahwa perbedaan jumlah fekunditas secara umum belum diketahui dengan pasti. Namun, ada kemungkinan bahwa yang menyebabkannya adalah perbedaan wilayah sampel (La Sara, et al., 2002). Faktor lain yang menyebabkan produktivitas jumlah telur pada rajungan bervariasi dapat disebabkan faktor lingkungan dan faktor parasit penyebab penyakit yang sewaktu-waktu menyerang rajungan betina yang sedang dalam tahap reproduksi (Al-Rumaidh (2002).

\section{Ukuran Pertama Matang Gonad}

Nilai 50\% kumulatif jumlah persentase rajungan yang diperoleh merupakan ukuran $\mathrm{CW}$ pertama matang gonad (Gambar 6). Data tersebut menunjukan perbedaan ukuran CW pertama kali matang gonad rajungan jantan $(72,4 \mathrm{~mm})$ dan betina $(78,5 \mathrm{~mm})$. Rajungan betina matang pada ukuran $\mathrm{CW}$ lebih besar dibandingkan ukuran $\mathrm{CW}$ rajungan betina. Hal ini berkaitan dengan perbedaan jenis kelamin dan pertumbuhan rajungan itu sendiri. Lagler et al. (1997), menyatakan beberapa faktor yang memengaruhi ukuran pertama kali matang gonad antara lain adalah perbedaan spesies, umur dan ukuran, serta sifat-sifat fisiologi individu yang berbeda jenis kelamin dan juga kondisi lokasi berpijah yang sesuai. Diantara sample rajungan betina yang diperoleh dalam penelitian ini, terdapat kisaran ukuran $\mathrm{CW}$ 48,40 - 62,49 mm sudah mencapai matang seksual (TKG IV) yang jumlahnya $0,33 \%$. Kondisi ini bisa terjadi jika tekanan penangkapan rajungan cukup intensif sehingga secara alamiah rajungan tersebut malakukan strategi dengan mempercepat proses matang gonad agar cepat bereproduksi. Tingkat eksploitasi rajungan jantan di perairan Toronipa termasuk kategori tinggi $(\mathrm{E}>0,5)$ atau overfishing (Muchtar, 2016). Trippel et al. (1997 dalam Sunarto $d k k$. 2010) menjelaskan bahwa spesies yang mengalami tekanan penangkapan akan cenderung matang gonad pada ukuran lebih kecil.

Beberapa hasil penelitian melaporkan ukuran $\mathrm{CW}$ pertama matang gonad rajungan yang berbeda-beda. Sebagian menunjukan ukuran CW pertama matang gonad lebih kecil dan sebagian lainnya mempunyai ukuran CW pertama matang gonad lebih besar dari data penelitian di perairan Toronipa ini. Misalnya, rajungan jantan dan betina di Perairan Australia Selatan umumnya mencapai kematangan seksual pada ukuran CW 70 - $90 \mathrm{~mm}$. Ukuran ini telah berumur sekitar satu tahun (Svane dan Hooper, 2004).

Perbedaan ukuran matang gonad rajungan di beberapa perairan yang diuraikan sebelumnya dapat disebabkan berbagai faktor. Sulistiono et al. (2009) menjelaskan ukuran pertama kali matang gonad setiap 
spesies dapat berbeda, bahkan spesies yang sama namun berbeda habitatnya dapat matang gonad pada ukuran yang berbeda. Ukuran $\mathrm{CW}$ pertama kali matang gonad di perairan Tonipa ini termaksud kecil berdasarkan ukuran rajungan yang ditetapkan Menteri Kelautan dan Perikanan (Peraturan No. I/PERMEN$\mathrm{KP} / 2015$ ).

\section{KESIMPULAN}

Walaupun potensi reproduksi rajungan betina cukup tinggi, penangkapan rajungan di perairan ini harus hati-hati karena terdapat indikasi sudah terjadi penangkapan intensif sebagaimana ditunjukan oleh ukuran CW pertama matang gonad relatif kecil yaitu masing-masing $72,4 \mathrm{~mm}$ (jantan) and $78,5 \mathrm{~mm}$ (betina).

Ucapan Terima Kasih: kepada nelayan di Toronipa kami menyampaikan terima kasih karena telah membantu mengumpulkan sample rajungan selama penelitian. Kepada staf Laboratorium Pengujian FPIK kami juga menyampaikan terima kasih karena sudah membantu menganalisis sample penelitian ini.

\section{DAFTAR PUSTAKA}

Al-Rumaidh, M.J. 2002. The Biology, Population Dynamics and Fishery Management of the Blue Swimming Crab, Portunuspelagicus (Linnaeus, 1758), in Bahraini Waters. Ph.D Dissertation. University of Wales, Bangor. 298 p.

Araujo, M.D.S.L.C.D., and J.J.P.R.D. Lira. 2012. Condition Factor and Carapace Width Versus Wet Weight Relationship in the Swimming Crab Callinectesdanae Smith 1869 (Decapoda: Portunidae) at the Santa Cruz Channel, Pernambuco State, Brazil. Nauplius, 20 (1): 4150.

Ayal, D. and ozogul, Y. 2011. The Chemical Composition of Sexually Mature Blue Swimmer Crab (Portunus pelagicus, Linnaeus 1758) in The Mersin Bay. J FisheriesSciences.com. 5(4): 308-316.

Branco, J.O., and H.A.A. Fracasso. 2004. Biologia Populacional de Callinectesornatus (Ordway) Penha, Santa Catarina, Brasil. Revista Brasileira de Zoologia, 21(1): 91-96.

Clarke, K. and S. Ryan. 2004. Ecological Assesment of the Queensland Blue Swimming Crab Pot
Fishery. Department of Primary Industries and Fisheries. Queensland Government. 100 p.

Costa, T.M. and Negreiros-Fransozo, M.L. 1998. The Reproductive Cycle of Callinectes danae Smith, 1869 (Decapoda, Portunidae) in the Ubatuba Region, Brazil. Crustaceana, 71(6): 615-627.

Edgar, G. J., 1990. Predator-prey interactions in seagrass beds. II. Distribution and Diet of the Blue Manna crab $P$. pelagicus Linnaeus at Cliff Head, Western Australia. Journal of Experimental Marine Biology and Ecology, 139: 23-32.

Hosseini, M., A. Vazirizade., Y. Parsa., A. Mansori. 2012. Sex Ratio, Size Distribution and Seasonal Abundance of Blue Swimming Crab, Portunus pelagicus (Linnaeus, 1758) in Persian Gulf Coasts, Iran. World Applied Sciences Journal, 17 (7): 919 - 925.

Ikhwanuddin, M., M.N. Azra., H.S. Aimuni., A.B.A. Munafi. 2012. Fecundity, Embryonic and Ovarian Development of Blue Swimming Crab, Portunus pelagicus (Linneaus, 1758) in Coastal Water of Johor Malaysia. Pakistan Journal of Biological Sciences, 15 (15): 720-728.

Josileen, J. 2013. Fecundity Of The Blue Swimmer Crab, Portunuspelagicus (Linnaeus, 1758) (Decapoda, Brachyura, Portunidae) Along the Coast of Mandapam, Tamil Nadu, India. Crustaceana, 86 (1): 48-55.

Kailola, P.J., Williams, M.J., Stewart, P.C., Russell, E.R., McNee, A. \& Grieve, C. (1993). Australian Fisheries Resources. Bureau of Resource Sciences and the Fisheries Research and Development Corporation, Canberra, Australia, pp. 266-268.

Kamrani, E., A.N. Sabili., M. Yahyavi. 2010. Stock Assessment and Reproductive Biology of the Blue Swimming Crab, Portunuspelagicus in Bandar Abbas Coastal Waters, Northern Persian Gulf. Journal of the Persian Gulf, 1 (2): 11-22.

Kangas, M. I. 2000. Synopsis of The Biology and Exploitation of the Blue Swimmer Crab, Portunus pelagicus Linneaeus, in Western Australia. Fisheries Research No. 121. Fisheries Western Australia. Western Australia. Perth. 22 hal.

Kumar, M., G. Ferguson, Y. Xiao, G. Hooper and S. Venema. 2000. Studies on Reproductive Biology and Distribution of the Blue Swimmer Crab (Portunus pelagicus) In South Australian Waters. South Australian Research and Development Institute (SARDI), Australia. 35p. 
Kunsook, C., N. Gajaseni., N. Paphavasit. 2014. A Stock Assessment of the Blue Swimming Crab Portunus pelagicus (Linnaeus, 1758) for Sustainable Management in Kung Krabaen Bay, Gulf of Thailand. Tropical Life Sciences Research, 25 (1), 41-59.

La Sara. 2001. Ecology and Fisheries of Mud Crab (Scylla serrata) in Lawele Bay, Southheast Sulawesi, Indonesia. Ph.D. Dissertation College of Fisheries and Ocean Science, University of the Philippines, Miagao,Iloilo. Philippines.

La Sara, J.A. Ingles, R.B. Baldevarona, R.O. Aguilar, L.V. Laureta and S. Watanabe. 2002. Reproductive Biology of Mud Crab Scylla serrata in Lawele Bay, Southeast Sulawesi, Indonesia. Crustacean Fisheries, 88-95.

La Sara. 2010. Study on The Size Structure and Population Parameters of Mud Crab Scyllaserrata in Lawele Bay, Southeast Sulawesi, Indonesia. Journal of Coastal Development, 13 (2): 133-147.

La Sara, Muskita W. H., Astuti O., Safilu, 2016a. The reproductive biology of blue swimming crab Portunus pelagicus in Southeast Sulawesi waters, Indonesia. AACL Bioflux 9(5):1101-1112.

La Sara, Muskita W. H., Astuti O., Safilu, 2016b. Effort in harvest control for blue swimming crab (Portunus pelagicus) in Southeast Sulawesi, Indonesia. Paper presented in the Crustacean Society Mid-Year Meeting 2016, National University of Singapore, Singapore, 11-13 July 2016.

La Sara, Muskita W. H., Astuti O., Safilu, 2017 Some population parameters of blue swimming crab (Portunus pelagicus) in Southeast Sulawesi waters, Indonesia. AACL Bioflux 10(3): 587-601.

Lestang, S.D., N.G. Hall., I.C. Potter., 2003. Reproductive Biology of the Blue Swimmer Crab (Portunuspelagicus, Decapoda: Portunidae) in Five Bodies of Water on the West Coast of Australia. Fish. Bull. 101:745-757.

Mehanna, S.F., S. Khvorov., M. Al-Sinawy., Y. S. AlNadabi., M. N. Al-Mosharafi. 2013. Stock Assessment of the Blue Swimmer Crab Portunus pelagicus (Linnaeus, 1766) from the Oman Coastal Waters. International Journal of Fisheries and Aquatic Sciences, 2 (1): 1-8.

NMFS. 2012. Swimming Crab Trade Data. Data Available from: http://www.st.nmfs.noaa.gov/st1/trade/index.htm
Potter, I. C. and de Lestang. 2000. Biology of the Blue Swimmer Crab Portunus Pelagicus in Leschenault Estuary and Boombana Bay, SouthWestern Australia. J. Royal Soc. Western Australia 83; 443-458.

Quinn, N.J. and Kojis, B.L., 1987. Reproductive Biology of Scylla spp. (Crustacea: Portunidae) from the Labu Estuary in Papua New Guinea. Bull. Mar. Sci. 41(2): 234-241.

Rodrigues, M.A., M.F. Heberle., F. D'incao. 2011. Fecundity Variation and Abundance of Female Blue Crabs CallinectesSapidus Rathbun, 1896 (Decapoda, Brachyura, Portunidae) in the Patos Lagoon Estuary, RS, Brazil. Atlântica, Rio Grande, 33 (2): 141-148.

Safaie, M., J. Pazooki., B. Kiabi., M.R. Shokri. 2012. Reproductive Biology of Blue Swimming Crab, Portunus segnis (Forskal, 1775) in Coastal Waters of Persian Gulf and Oman Sea, Iran. Iranian Journal of Fisheries Sciences, 12 (2): 430444.

Sahib, I.M.A. 2012. Some Biological Aspects of the Swimming Crab Portunus pelagicus (Linnaeus, 1766) (Decapoda: Portunidae) in NW Arabian Gulf. Mesopot. J. Mar. Sci., 27 (2): 7887.

Soundarapandian, P., D. Varadharajan., T. Anand. 2013. Male Reproductive System of Blue Swimming Crab, Portunuspelagicus (Linnaeus, 1758). Journal Cytol Histol 5 (206): 1-8.

Stephenson, W. \& B. Campbell, 1959. The Australian Portunids (Crustacea: Portunidae) III. The Genus Portunus. Australian Journal of Marine and Freshwater Research, 10(1): 84-124.

Sulistiono., K.D. Soenanthi., Y. Ernawati. 2009. Aspek reproduksi ikan lidah, Cynoglossus linguna H.B. 1822 di perairan Ujung Pangkah, Jawa imur. Jurnal Ikhtiologi Indonesia9:175-185.

Sumpton, W., M. Potter \& G. Smith, 1994. Reproduction and Growth of the Commercial Sand Crab, Portunus pelagicus (L.) in Moreton Bay, Queensland. Asian Fisheries Science, 7: 103-113.

Svane, I., and Hooper, G.E. 2004. Blue Swimmer Crab (Portunus pelagicus) Fishery. Fishery Assessment Report to PIRSA for Blue Crab Fishery Management Committee South Australian Research and Development Institute. Aquatic Sciences Publication. 3: 274. 
JURNAL SAINS dan INOVASI PERIKANAN / Journal of Fishery Science and Innovation

Vol. 1, No. 2, 16-25, Juli 2017

Takween, W., and N.A. Qureshi. 2005. Population Structure and Reproductive Biology of Four Speciesof Swimming Crabs (Crustacea: Brachyura: Portunidae) From Coastal Area of Karachi, Pakistan. Pakistan J. Marine Sci., 14:107-121.

Williams, M. J., 1982. Natural Food and Feeding in the Commercial Sand Crab P. pelagicus Linnaeus, 1766 (Crustacea: Decapoda: Portunidae) in Moreton Bay. Queensland Journal of Experimental Marine Biology and Ecology, 59: 165-176.

Xiao, Y. and Kumar, M., 2004. Sex ratio, and Probability of Sexual Maturity of Females at Size, of the Blue Swimmer Crab, Portunuspelagicus Linneaus, off Southern Australia, SARDI Aquatic Sciences Centre, Hamra Avenue, West Beach, SA 5024, Australia , Fisheries Research, 68: 271282. 